\title{
Use of Non-Conventional Cell Disruption Method for Extraction of Proteins from Black Yeasts
}

\author{
Maja Čolnik, Mateja Primožič, Željko Knez and Maja Leitgeb* \\ Laboratory for Separation Processes and Product Design, Faculty of Chemistry and Chemical Engineering, University \\ of Maribor, Maribor, Slovenia
}

\section{OPEN ACCESS}

Edited by:

Vijai Kumar Gupta,

NUI Galway, Ireland

Reviewed by:

Giuseppe Spano,

University of Foggia, Italy

Christopher L. Hemme,

University of Rhode Island, USA

*Correspondence:

Maja Leitgeb

maja.leitgeb@um.si

Specialty section:

This article was submitted to

Microbiotechnology, Ecotoxicology

and Bioremediation,

a section of the journal

Frontiers in Bioengineering and

Biotechnology

Received: 26 February 2016 Accepted: 29 March 2016

Published: 15 April 2016

Citation:

Čolnik M, Primožič M, Knez Ž and Leitgeb M (2016) Use of Non-

Conventional Cell Disruption Method

for Extraction of Proteins from

Black Yeasts.

Front. Bioeng. Biotechnol. 4:33. doi: 10.3389/fbioe.2016.00033
The influence of pressure and treatment time on cells disruption of different black yeasts and on activities of extracted proteins using supercritical carbon dioxide process was studied. The cells of three different black yeasts Phaeotheca triangularis, Trimatostroma salinum, and Wallemia ichthyophaga were exposed to supercritical carbon dioxide (SC $\left.\mathrm{CO}_{2}\right)$ by varying pressure at fixed temperature $\left(35^{\circ} \mathrm{C}\right)$. The black yeasts cell walls were disrupted, and the content of the cells was spilled into the liquid medium. The impact of SC $\mathrm{CO}_{2}$ conditions on secretion of enzymes and proteins from black yeast cells suspension was studied. The residual activity of the enzymes cellulase, $\beta$-glucosidase, $\alpha$-amylase, and protease was studied by enzymatic assay. The viability of black yeast cells was determined by measuring the optical density of the cell suspension at $600 \mathrm{~nm}$. The total protein concentration in the suspension was determined on UV-Vis spectrophotometer at $595 \mathrm{~nm}$. The release of intracellular and extracellular products from black yeast cells was achieved. Also, the observation by an environmental scanning electron microscopy

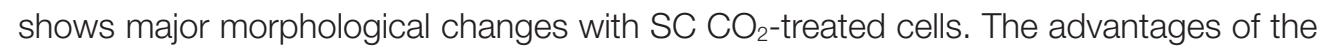
proposed method are in a simple use, which is also possible for heat-sensitive materials on one hand and on the other hand integration of the extraction of enzymes and their use in biocatalytical reactions.

Keywords: $P$. triangularis, W. ichthyophaga, $T$. salinum, supercritical carbon dioxide, enzyme activity, cell disruption

\section{INTRODUCTION}

The widespread use of fungi in different biotechnological processes can be attributed to their intrinsic characteristics. They can secrete a wide range of extracellular enzymes and proteins, which represents a powerful biochemical tool for the catalysis of a number of valuable reactions (i.e., regio- and stereoselective reactions). A lot of biological molecules are inside the cell, and they must be released from it. This could be achieved by cell disruption (lysis). Cell disruption is a sensitive process because of the cell wall's resistance to the high osmotic pressure inside them. Furthermore, difficulties arise from a non-controlled cell disruption that results from an unhindered release of all intracellular products (proteins nucleic acids, and cell debris) as well as the requirements for cell disruption without the desired product's denaturation.

The large amounts of toxic solvents and energy required make the conventional disruption methods unattractive. Therefore, the development of an efficient recovery method is important. Supercritical fluids have unique physicochemical properties such as high densities and low viscosities and that make them suitable as extraction solvents. Carbon dioxide $\left(\mathrm{CO}_{2}\right)$ is the most beneficial SCF used in extraction processes. $\mathrm{SC} \mathrm{CO}_{2}$ is non-flammability, non-toxicity, as well as the selectivity 
of the process, and the ease of recovery are the most important features of its usage (Darani and Mozafari, 2009; Mun et al., 2011). $\mathrm{SC} \mathrm{CO}_{2}$ is the most popular used SCF, since it is easy to use and it is inexpensive solvent. $\mathrm{SC} \mathrm{CO}_{2}$ treatment is an alternative method for the inactivation of microorganisms. The higher the temperature and pressure of the $\mathrm{SC} \mathrm{CO}_{2}$, the higher the percentage of the inactivated microorganisms. At higher pressures, the solubility of $\mathrm{CO}_{2}$ in water increases, which allows the formation of carbonic acid. Higher temperatures stimulate the diffusion of $\mathrm{CO}_{2}$. Fluidity of the membrane increases, and consequently to improve the excretion of cellular material from the cells (Garcia-Gonzalez et al., 2007; Wimmer and Zarevúcka, 2010; Mun et al., 2011; Ji et al., 2012). Generally, treating microorganisms with $\mathrm{SC} \mathrm{CO}_{2}$ at higher pressure or temperature, or treating them for a longer time results in greater microbial reduction than a treatment at lower pressure or temperature, or treating them for shorter times (Wimmer and Zarevúcka, 2010). However, at too high temperature, enzyme deactivation can occur. The use of $\mathrm{SC} \mathrm{CO}_{2}$ for the inactivation of microorganisms can be safely used in foods and bioactive substances at relatively low temperatures (Debs-Louka et al., 1999; Hong and Pyun, 2001; Erkmen, 2003; Wimmer and Zarevúcka, 2010; Ortuño et al., 2012). However, $\mathrm{SC} \mathrm{CO}_{2}$ can also serve as a solvent for the extraction of intracellular components from microbial cells or for isolation of products from the reaction mixture in the production of biomass (Spilimbergo et al., 2003; Wimmer and Zarevúcka, 2010; Ceni et al., 2016).

The potential application of some organisms is often determined by their taxonomic and phylogenetic diversity, as well as their occurrence and adaptation to various habitats (Raghukumar, 2012). Salinity is the most defining feature of the oceanic environment. Salt pans are an attractive source for extremophilic microorganisms (Raghukumar, 2012). No obligate marine fungi have been detected in salt pans till now, but they present a suitable environment for fungi, such as black yeasts, Trimatostroma salinum, Hortaea werneckii, and Pheaotheca triangularis, which were isolated from salt pans of 15-30\% salinity (Zalar et al., 1999; Gunde-Cimerman et al., 2000). Black yeast is a term subscribing a group of fungi that is quite heterogeneous from the taxonomy and phylogenetic point of view but having in common melanized cell walls and the formation of daughter cells by yeast-like multilateral or polar budding (Rosa and Peter, 2006). Black yeasts have a unique ability to survive where other microorganisms are rarely observed. Their name comes from the fact they produce the dark pigment melanin, unlike other yeasts. Melanin is the expression of the dark brown to black pigments phenol compounds formed by oxidative polymerization and assemblies of proteins and carbohydrates (Sterflinger, 2006; Kutty, 2009). The proteins of halophilic archaea are highly adapted to function at high ionic strength. Because of this extreme saline environment, halophilic proteins represent a valuable resource for understanding the processes of natural selection and adaptive evolution.

The study was focused on the possibility to obtain the active form of cellulase, $\alpha$-amylase, $\beta$-glucosidase, and protease after destruction of black yeast cell walls with $\mathrm{SC} \mathrm{CO}_{2}$. For comparison, the cell wall could be broken using different mechanical methods, e.g., the homogenization, sonication, and bead milling. Homogenization is an efficient way to apply shearing forces to break down cell wall of microorganisms. It may be used to disrupt bacteria and yeast cells at the laboratory and industrial scale. The disadvantage of the valve homogenizers when applied to extraction of heat sensitive materials is the need for external cooling, which can only be applied after the disruption (with the concomitant temperature increase) has taken place (Geciova et al., 2002). Sonication is a mechanical method where cells are broken by sonic cavitation. Sonication is very easy to adjust by amplitude setting, a sonication time, as well as by choosing the right equipment; it is possible to disrupt cell membranes very gently or very abruptly, depending on the cell structure. The heat, generated by the ultrasound process, must be dissipated, and high noise levels appear. Therefore, the use of this method is very expensive. Significant degradation of enzymes due to heat denaturation may occurred because of insufficient cooling in close proximity of the sonication probe (Geciova et al., 2002). The bead mill provides a simple and effective way for disruption of different types of microorganisms. The degree of disruption increases with bead loading due to increased bead-to-bead interaction. Consequently, heating and power consumption also increase. The enzymes found in soluble form in the cytoplasm are released with higher efficiency using smaller beads. For enzymes bound to cytoplasmic membrane or in periplasmic space, bigger glass beads can be used (Geciova et al., 2002). This method has many disadvantages such as uneven processing, protein denaturation, low efficiency while relatively high energy consumption, complex separation of milling medium, and product- and time-consuming cleaning. Although the mechanical methods are favored due to economic advantages, SCF usage has significant advantages (described previously) to use them for cell disruption (Darani and Mozafari, 2009). Usage of $\mathrm{SC} \mathrm{CO}_{2}$ in biocatalysis has an important preference; it can act as a medium for opening the cells and carrying out the biocatalytical reaction at the same time.

The impact of different experimental conditions (pressure and incubation time) on viability of cells, total protein concentrations, and cellulase, $\alpha$-amylase, $\beta$-glucosidase, and protease activities in the suspensions of black yeasts during $\mathrm{SC} \mathrm{CO}_{2}$ treatment was investigated.

\section{MATERIALS AND METHODS}

\section{Materials}

Pheaotheca triangularis EXF-206, T. salinum EXF-295, and Wallemia ichthyophaga EXF-5676 were obtained from the University of Ljubljana, Biotechnical Faculty, Department of Biology (Ljubljana, Slovenia). Carbon dioxide 2.5 (purity 99.5\%) was supplied by Messer MG (Ruše, Slovenia). Peptone from meat, potassium phosphate, potassium dihydrogen phosphate, sodium carbonate, sodium bicarbonate, and acetic acid were purchased from Merck (Darmstadt, Germany). Sodium pyrophosphate decahydrate $(\geq 99.0 \%)$, sodium phosphate monobasic $(\geq 99.0 \%)$, sodium phosphate dibasic $(\geq 99.0 \%)$, albumin from bovine serum (BSA) $(\geq 98.0 \%)$, malt extract, agar, $\mathrm{D}-(+)$-glucose, sodium acetate, Sigmacell, glucose assay reagent, Casein, Hammarsten bovine, trichloroacetic acid (TCA), D-(-)-Salicin ( $\geq 99.0 \%)$, 
starch azure, and sodium chloride were supplied from Sigma (Schnelldorf, Germany).

\section{Preparation of Black Yeasts Suspension}

The microbial strains used in this study were $P$. triangularis, T. salinum, and W. ichthyophaga. P. triangularis and T. salinum grown on malt extract agar (MEA) for 5-7 days at room temperature, while cells of $W$. ichthyophaga grown on $\mathrm{MEA} 17 \% \mathrm{NaCl}$ at the same condition. Each of black yeast cells were suspended to sterile saline solutions. The cultures used in all experiments were freshly prepared by the same procedure.

\section{Treatment of Black Yeasts with $\mathrm{SC} \mathrm{CO}_{2}$}

Experiments were carried out in a $70-\mathrm{mL}$ high-pressure batch reactor (Figure 1). The sterile ampoule was filled with freshly prepared cell suspension of black yeast and placed into the reactor. The reactor was tightly closed and immersed in an oil bath at the fixed temperature of $35^{\circ} \mathrm{C}$. Next, the reactor was charged to the desired pressure of 10 or $30 \mathrm{MPa}$ with cooled $\mathrm{CO}_{2}$. After the cell suspension of black yeast was exposed to $\mathrm{SC}^{\mathrm{CO}_{2}}$ for a certain time, the pressure was released slowly $(\Delta p / \Delta t=0.5$ $\mathrm{MPa} / \mathrm{min}$ ) to atmospheric pressure. The culture broth in ampule was immediately removed from the reactor and transferred into the sterile tube, for the subsequent analyses. The reactor was rinsed with distilled water and autoclaved.

\section{Determination of Enzymatic Activities}

The optical densities of black yeast cells in a suspension before incubation in $\mathrm{SC} \mathrm{CO}_{2}$ were between 0.48 and 0.52 . Before further analysis, each of the cell suspensions of black yeasts was centrifuged for 2 min after incubation in $\mathrm{SC} \mathrm{CO}_{2}$. The supernatant without cells and debris was analyzed spectrophotometrically.

The amount of total proteins was determined with Bradford method (Bradford, 1976). Activities of the cellular enzymes of black yeasts, $\alpha$-amylase, cellulase, $\beta$-glucosidase, and

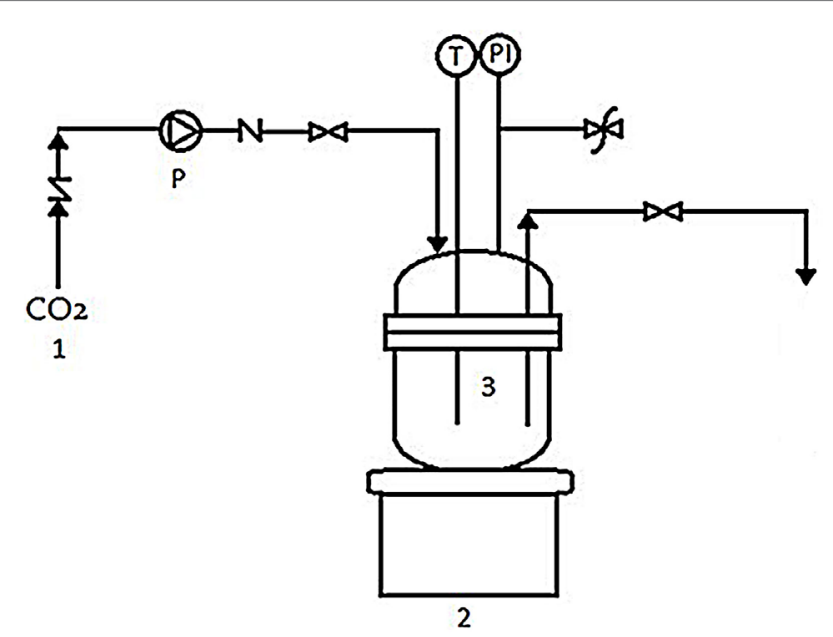

FIGURE 1 | High-pressure batch reactor: (1) $\mathrm{CO}_{2}$ tank, (2) heater, (3) high-pressure batch reactor, $(P)$ high-pressure pump, (T) temperature regulator, and $(\mathrm{PI})$ pressure indicator protease, which are the most commonly used enzymes in applied biocatalysis, were determined by the UV-Vis spectrophotometer at wavelengths of 595, 340, and $280 \mathrm{~nm}$ before and after incubation of the black yeasts culture in $\mathrm{SC} \mathrm{CO}_{2} \cdot \mathrm{pH}$ of black yeasts suspensions was measured with a $\mathrm{pH}$ meter (Hanna instruments) before and after incubation in $\mathrm{SC} \mathrm{CO}_{2}$. The optical density of black yeast cell suspensions was determined at $600 \mathrm{~nm}$ by the $\mathrm{UV}-\mathrm{Vis}$ spectrophotometer.

\section{Cellulase Activity Assay}

Sigmacell solution $(4 \mathrm{~mL}, 5 \% w / v)$ was added to $1 \mathrm{~mL}$ of cell suspension of studied culture and mixed at $37^{\circ} \mathrm{C}$ for $120 \mathrm{~min}$ with moderate shaking. After that, the suspension was immediately transferred into an ice bath. After the suspension was settled, it has been centrifuged for 2 min to clarify. To $3 \mathrm{~mL}$ of a substrate solution, $100 \mu \mathrm{L}$ of the supernatant was added. The increase of absorbance at $340 \mathrm{~nm}$ followed at $25^{\circ} \mathrm{C}$ with a UV-Vis spectrophotometer was used to define the cellulase activity.

\section{$\boldsymbol{\alpha}$-Amylase Activity Assay}

Amylose azure $(90 \mathrm{mg}$ ) was dissolved in $9 \mathrm{~mL}$ of potassium phosphate buffer, and the suspension was incubated at $37^{\circ} \mathrm{C}$. Then, $0.5 \mathrm{~mL}$ of studied culture cell suspension was added, mixed by swirling, and placed in a shaker bath at $37^{\circ} \mathrm{C}$ for $10 \mathrm{~min}$. Acetic acid solution $(0.5 \mathrm{~mL})$ was poured into the reaction mixture. The resulting mixture was filtered. The increase of absorbance at $595 \mathrm{~nm}$ was used to define the $\alpha$-amylase activity. All absorbance measurements were performed with a UV-Vis spectrophotometer. The activity was expressed as the change in absorbance at $595 \mathrm{~nm}$ per minute per solid of $\alpha$-amylase.

\section{Protease Activity Assay}

Casein solution $(1 \mathrm{~mL})$ was added to previously prepared phosphate buffer. Solution was stirred and heated up to $35^{\circ} \mathrm{C}$. Then, $0.5 \mathrm{~mL}$ of phosphate buffer and $0.5 \mathrm{~mL}$ of selected black yeast cell suspension were pipetted and incubated at $35^{\circ} \mathrm{C}$ for $20 \mathrm{~min}$. After incubation, $3 \mathrm{~mL}$ of TCA was added and incubated at room temperature for $30 \mathrm{~min}$. Thus, prepared reaction mixture was centrifuged at $3000 \mathrm{rpm}$ for $20 \mathrm{~min}$. Supernatant was measured at $280 \mathrm{~nm}$ on UV-Vis spectrophotometer.

\section{$\beta$-Glucosidase Activity Assay}

Salicin solution $(2 \mathrm{~mL})$ was pipetted into centrifuge falcon tubes and incubated at $37^{\circ} \mathrm{C}$ for exactly $10 \mathrm{~min}$. Then, $2.5 \mathrm{~mL}$ of carbonate-bicarbonate buffer solution was added. This stopped reaction mixture was used in next step. To $0.9 \mathrm{~mL}$ of a glucose reagent solution, $100 \mu \mathrm{L}$ cell suspension of selected black yeast was added, mixed by inversion, and the reaction was monitored at $340 \mathrm{~nm}$ with a UV-Vis spectrophotometer.

\section{RESULTS AND DISCUSSION}

\section{Viability of Black Yeast Cells Exposed to $\mathrm{SC} \mathrm{CO}$}

Wallemia ichthyophaga, T. salinum, and P. triangularis type strains were isolated from the hypersaline water of the Sečovlje solar saltern. W. ichthyophaga requires growth media with reduced water 
activity $\left(a_{\mathrm{w}}\right)(0.959-0.771)$. It grows better on media with high concentration of $\mathrm{NaCl}$ (Zalar et al., 2005a). It is a fungus from the genus Wallemia (Wallemiales, Wallemiomycetes) that grows only at salinities between $10 \%(w / v) \mathrm{NaCl}$ and $32 \%(w / v)$ saturated $\mathrm{NaCl}$ solution (Zajc et al., 2014). Therefore, W. ichthyophaga is the most halophilic fungus known to date (Zajc et al., 2014). T. salinum is a halophilic constitutively melanized fungi, which was isolated from hypersaline water at the highest salinity level during the season of salt production from Adriatic Sea. T. salinum was found also on mats and wood, immersed in brine, and is able to decompose wood at hypersaline conditions (Kogej et al., 2006). P. triangularis shows high adaptability to saline conditions, with the highest frequency of appearance in water between 22 and $28 \%$ salt concentration. $P$. triangularis was unable to grow on $32 \%$ salt and $26 \% \mathrm{NaCl}$ being the maximum (Gunde-Cimerman et al., 2000).

Two most common reasons for cell death are either structural damage (disruption of the envelopes, DNA conformational changes, ribosome alterations, or protein aggregation) or physiological dysfunctions (membrane selective permeability alterations or loss of function of key enzymes) (Manas and Pagan, 2005).

Viability of black yeast cells, W. ichthyophaga, P. triangularis, and T. salinum, in suspension culture after $\mathrm{SC} \mathrm{CO}_{2}$ treatment was determined. Selected black yeast cell suspension $(1 \mathrm{~mL})$ after treatment in $\mathrm{SCCO}_{2}$ was added in the sterile prepared meat extract broth and incubated at $25^{\circ} \mathrm{C}$ for growth. Viability of selected black yeast cells was monitored spectrophotometrically by measuring optical density of the culture broth at $600 \mathrm{~nm}$. Figure 2 shows that the viability of all studied cell cultures after $1 \mathrm{~h}$ incubation in $\mathrm{SC} \mathrm{CO}_{2}$ at 10 and $30 \mathrm{MPa}$ decreased. Cell viability decreased as the treatment time and pressure increased. $\mathrm{SC} \mathrm{CO}_{2}$ treatment decreased $\mathrm{pH}$ of the black yeast cell suspension from 5.9 to 4.5 because of the acidification of $\mathrm{CO}_{2}$ in the aqueous medium. The highest viability (90\%) after incubation in $\mathrm{SC} \mathrm{CO}_{2}$ was observed for the cell suspension of $W$. ichthyophaga at $10 \mathrm{MPa}, 35^{\circ} \mathrm{C}$, and incubation time of $30 \mathrm{~min}$. Quite high viability of black yeast W. ichthyophaga (55\%) was also observed after incubation in $\mathrm{SC} \mathrm{CO}$ for $30 \mathrm{~min}$ at $30 \mathrm{MPa}$ and $35^{\circ} \mathrm{C}$. The viability of cells in $P$. triangularis cell suspension after $30 \mathrm{~min}$ incubation in $\mathrm{SC} \mathrm{CO}_{2}$ at $10 \mathrm{MPa}$ and $35^{\circ} \mathrm{C}$ was about $30 \%$. The lowest viability of cells (20\%) after $30 \mathrm{~min}$ exposure to $\mathrm{SC} \mathrm{CO}_{2}$ was achieved in T. salinum cell suspension at $30 \mathrm{MPa}$ and $35^{\circ} \mathrm{C}$. In all cases, no survival of cells after $24 \mathrm{~h}$ of incubation in $\mathrm{SC}^{\circ} \mathrm{CO}_{2}$ was detected.

Based on these results, we can conclude that the cells of black yeast $W$. ichthyophaga are quite resistant to elevated pressure. Since, the W. ichthyophaga is known as the most halophilic fungus known to date (Zajc et al., 2014), the high viability of its cells exposed to high pressure $\mathrm{CO}_{2}$ could be attributed to its endurance under extreme conditions.

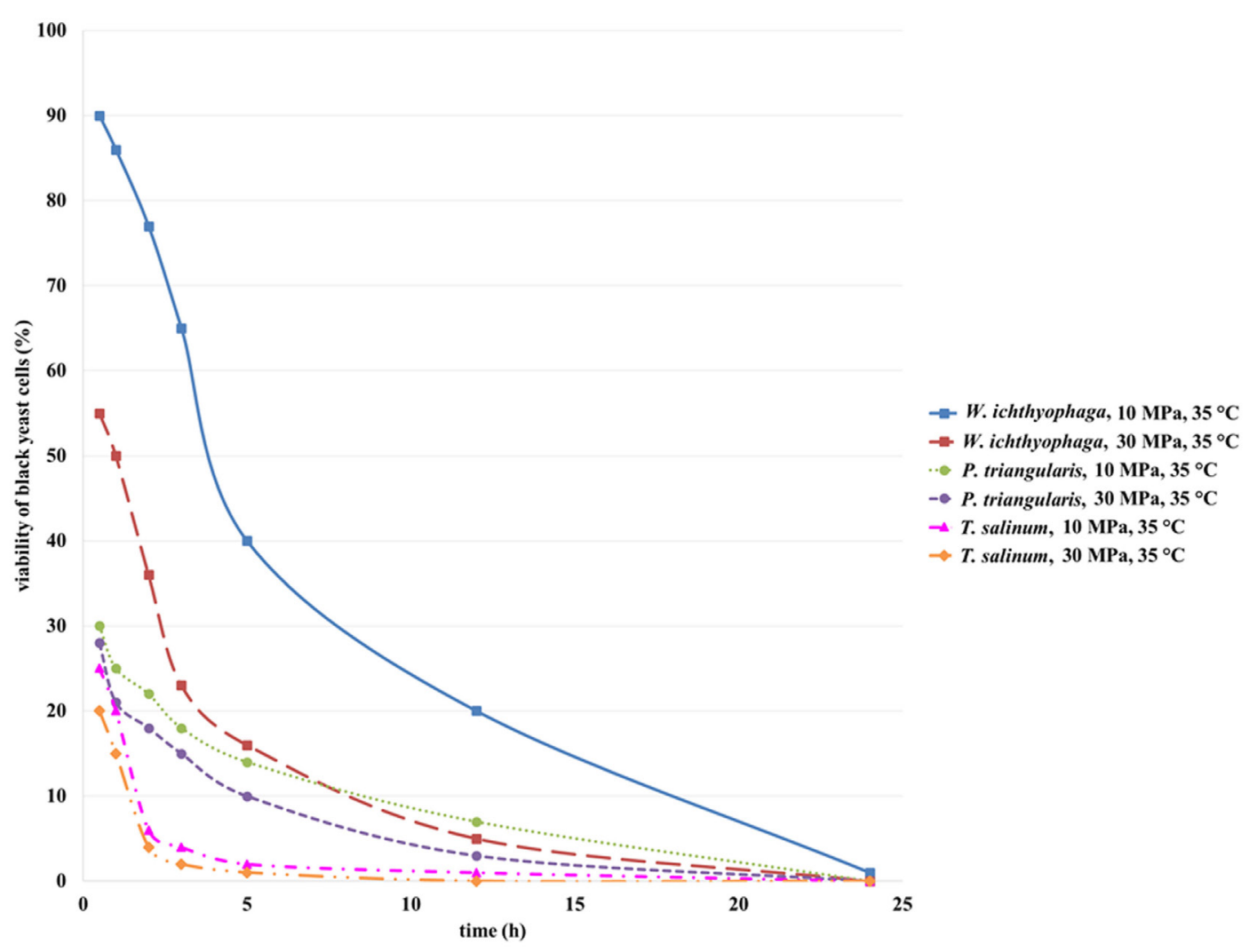

FIGURE 2 | Viability of $W$. ichthyophaga, $P$. triangularis, and $T$. salinum cells after incubation of cell suspensions in $\mathrm{SC} \mathrm{CO}_{2}$ at 10 and $30 \mathrm{MPa}$ and $35^{\circ} \mathrm{C}$ versus incubation time. 
Black yeast cells were observed under an environmental scanning electron microscope (ESEM) at different magnifications before and after incubation of cell suspensions in $\mathrm{SC} \mathrm{CO}_{2}$ (Figures 3A-F). SC $\mathrm{CO}_{2}$ has a significant impact on black yeast cells. As could be evident from Figures 3B,D,F, the cells exposed to $\mathrm{SC} \mathrm{CO}_{2}$ were very damaged and deformed. P. triangularis, T. salinum, and W. ichthyophaga cells were burst after exposed to SC $\mathrm{CO}_{2}$ and they lost their shape.

Supercritical fluid cell disruption is a process, wherein a sudden release of the applied $\mathrm{SC} \mathrm{CO}_{2}$ pressure results in its penetration into the cells. After expansion of gas within the cells, discharge of pressure damages the cell wall and consequently the cell disruption occurred (Darani and Mozafari, 2009). Higher pressure leads to inactivation of $P$. triangularis, T. salinum, and $W$. ichthyophaga cells. Viability of the cells was influenced by the physical properties of $\mathrm{CO}_{2}$, such as density and viscosity which were higher at $30 \mathrm{MPa}$ and $35^{\circ} \mathrm{C}$, compared to the physical properties of $\mathrm{CO}_{2}$ at $10 \mathrm{MPa}$ and $35^{\circ} \mathrm{C}$ (Table $\mathrm{S} 1$ in Supplementary Material). After $24 \mathrm{~h}$ incubation of cell suspensions in $\mathrm{SC}^{-C_{2}}$, almost all cells of $P$. triangularis, T. salinum, and W. ichthyophaga were dead (Figures 3B,D,F).

\section{Residual Concentration of Total Proteins in Suspension of Selected Black Yeast after Treatment with $\mathrm{SC} \mathrm{CO}_{2}$}

Residual concentration of proteins in cell suspension of the selected black yeast was determined by Bradford assay. The Bradford assay is fairly accurate, and samples that are out of range can be retested within minutes (Bradford, 1976). It is recommended for general use, especially for determining protein content of cell fractions and assessing protein concentrations for gel electrophoresis (Karthikeyan and Santosh, 2009).

The treated cell suspension of selected black yeast was centrifuged at 11,000 rpm. Supernatant was used for analysis.

Total residual protein concentration (Figure 4) for all studied cell suspensions increased with the increase of incubation time in $\mathrm{SC} \mathrm{CO}_{2}$. SC $\mathrm{CO}_{2}$ effects the black yeast cells by damaging the cell wall, and intracellular material can be removed from the cell and extracted in cell suspension. Consequently, eliminated intracellular proteins influence total protein concentration in cell suspensions of the studied black yeasts. Inside the black yeast cells free or on cellular structures bound enzymes are presented (intracellular enzymes). Besides, some excreted enzymes in the growth medium (extracellular enzymes) could be found. The highest residual protein concentration in the cell suspension of T. salinum was detected after $24 \mathrm{~h}$ of incubation in $\mathrm{SC}^{-\mathrm{CO}_{2}}$ at $30 \mathrm{MPa}, 35^{\circ} \mathrm{C}$ (Figure 4). Residual protein concentrations in the cell suspensions of $W$. ichthyophaga and $P$. triangularis after incubation in $\mathrm{SC} \mathrm{CO}_{2}$ increased, but were lower than those in the case of T. salinum regardless of the increase in pressure. Generally, at higher pressure, higher residual protein concentrations in all studied cell suspensions of black yeasts were detected. This coincides with the findings from the previous study of viability. The lowest residual protein concentration at both tested pressures was detected in $W$. ichthyophaga cell suspension, which is conditioned by the fact that for same tested culture, the highest cell viability at same conditions was determined. At lower cell viability, due to inactivation and burst of the cell, more proteins were extracted from the cell and consequently higher residual

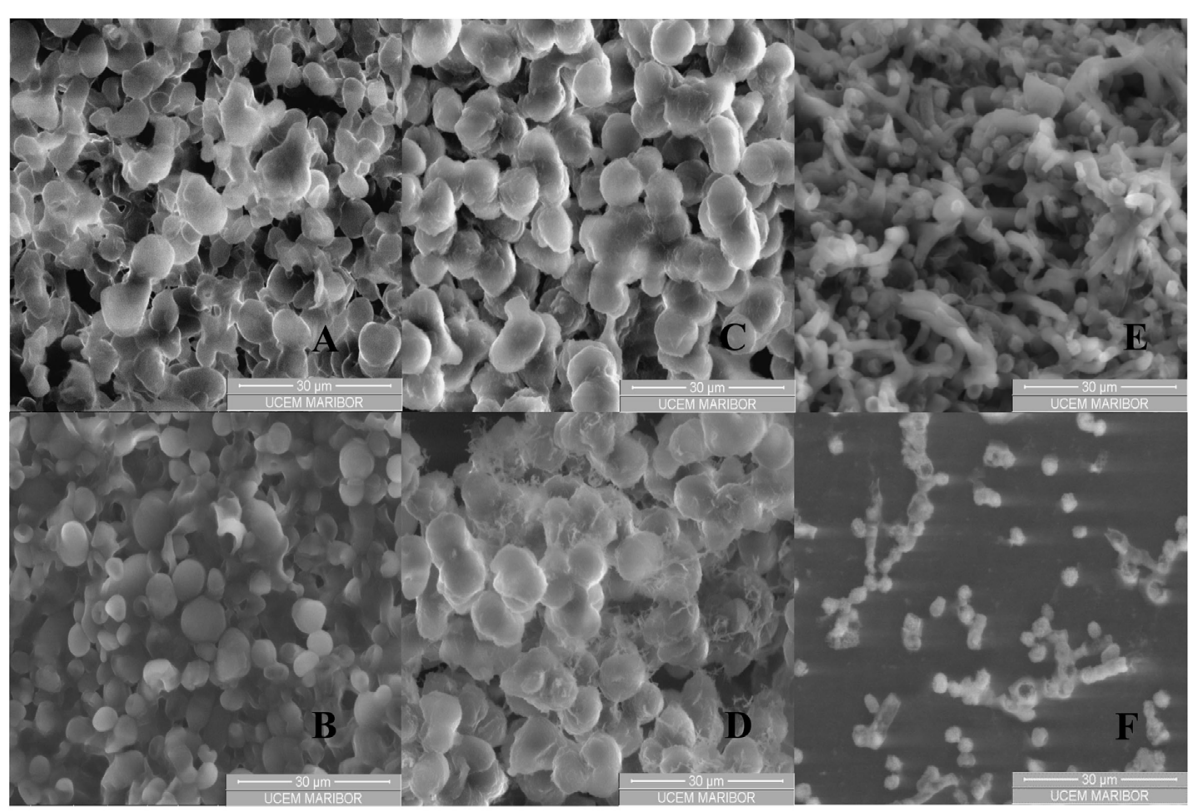

FIGURE 3 | ESEM images of black yeast cell suspension before and after incubation in $\mathbf{S C ~} \mathbf{C O}_{2}$. (A) $P$. triangularis cells before incubation in $\mathrm{SC} \mathrm{CO}$, (B) P. triangularis cells after $24 \mathrm{~h}$ incubation in $\mathrm{SC} \mathrm{CO}_{2}$ at $30 \mathrm{MPa}$ and $35^{\circ} \mathrm{C}$, (C) T. salinum cells before incubation in SC CO${ }_{2}$, (D) T. salinum cells after $24 \mathrm{~h}$ incubation in $\mathrm{SC} \mathrm{CO}_{2}$ at $30 \mathrm{MPa}$ and $35^{\circ} \mathrm{C}$, (E) W. ichthyophaga cells before incubation in $\mathrm{SC} \mathrm{CO}_{2}$, and (F) W. ichthyophaga cells after $24 \mathrm{~h}$ incubation in $\mathrm{SC} \mathrm{CO}$ at $30 \mathrm{MPa}$ and $35^{\circ} \mathrm{C}$ 


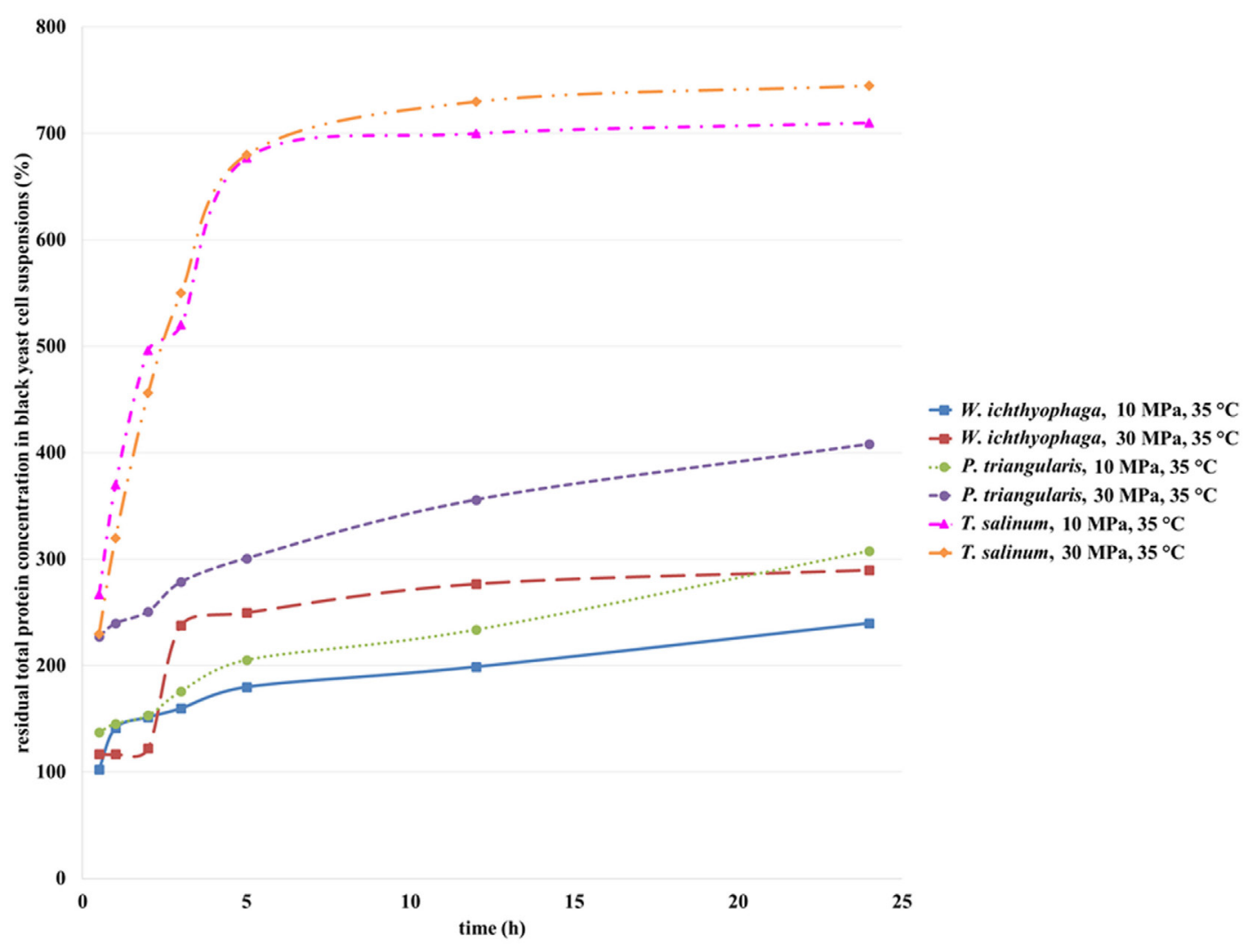

FIGURE 4 | Residual total protein concentration in cell suspensions of $W$. ichthyophaga, $P$. triangularis, and $T$. salinum after incubation in SC $\mathrm{CO}_{2}$ at 10 and $30 \mathrm{MPa}$ and $35^{\circ} \mathrm{C}$ versus incubation time.

protein concentration was detected, as it was the case in T. salinum cell suspension.

Mun et al. (2011) published about a high increase in insoluble protein concentration of Pseudomonas aeruginosa cell suspension after $\mathrm{SC} \mathrm{CO}_{2}$ treatment what may reflect the protein denaturation inside the cells because of the acidification during this process. This acidification may have led to the chemical and physical modification of the lipid bilayer of the membrane, thus causing disorder in the intracellular metabolic balance or removal of the vital constituents from cells. For this reason, activities of some enzymes in black yeast cell suspensions after exposure to the SC $\mathrm{CO}_{2}$ were studied.

\section{Activities of Cellulases, $\alpha$-Amylases, $\beta$-Glucosidases, and Proteases from Black Yeast Cell Suspensions Residual Activities of Cellulases}

Microbial cellulases have become the focal biocatalysts due to their complex nature and wide spread industrial applications. Cellulases are composed of independently folding, structurally and functionally discrete units called domains or modules, making cellulases module. Cellulases are inducible enzymes synthesized by a large diversity of microorganisms including both fungi and bacteria during their growth on cellulosic materials. These microorganisms can be aerobic, anaerobic, mesophilic, or thermophilic. Among them, the genera of Clostridium, Cellulomonas, Thermomonospora, Trichoderma, and Aspergillus are the most extensively studied cellulase producer (Kuhad et al., 2011).

Cellulase is an extracellular enzyme of T. salinum (Zalar et al., 2005b) and an intracellular enzyme of $P$. triangularis and W. ichthyophaga (personal communication, Zalar and Gunde-Cimerman, 2010), which activities were determined in the cell suspensions of studied cultures before and after incubation in $\mathrm{SC} \mathrm{CO}_{2}$. The activity of cellulase from black yeast cells before incubation in SC $\mathrm{CO}_{2}$ was defined as $100 \%$. Figure 5 shows the residual activity of cellulases in black yeast suspensions after incubation in $\mathrm{SC} \mathrm{CO}_{2}$. After exposure of $T$. salinum and $P$. triangularis cell suspensions in $\mathrm{SC}_{\mathrm{CO}_{2}}$ (Figure 5), the cellulase activities started to decrease as a function of incubation time. The reason for such behavior is probably due to enzyme deactivation at both examined pressures (10 and $30 \mathrm{MPa}$ ). It is well known that the activity of enzymes exposed to $\mathrm{CO}_{2}$ under high-pressure depend on enzyme species, water content in the solution, and the pressure and temperature of the reaction system. The three-dimensional structure of enzyme may be significantly altered under extreme conditions, causing their denaturation and consequent loss activity (Wimmer and Zarevúcka, 2010). Since the cellulase is an extracellular enzyme of T. salinum, it is more exposed to the extreme conditions (high pressure, acidification during the $\mathrm{SC} \mathrm{CO}_{2}$ treatment), than in the 


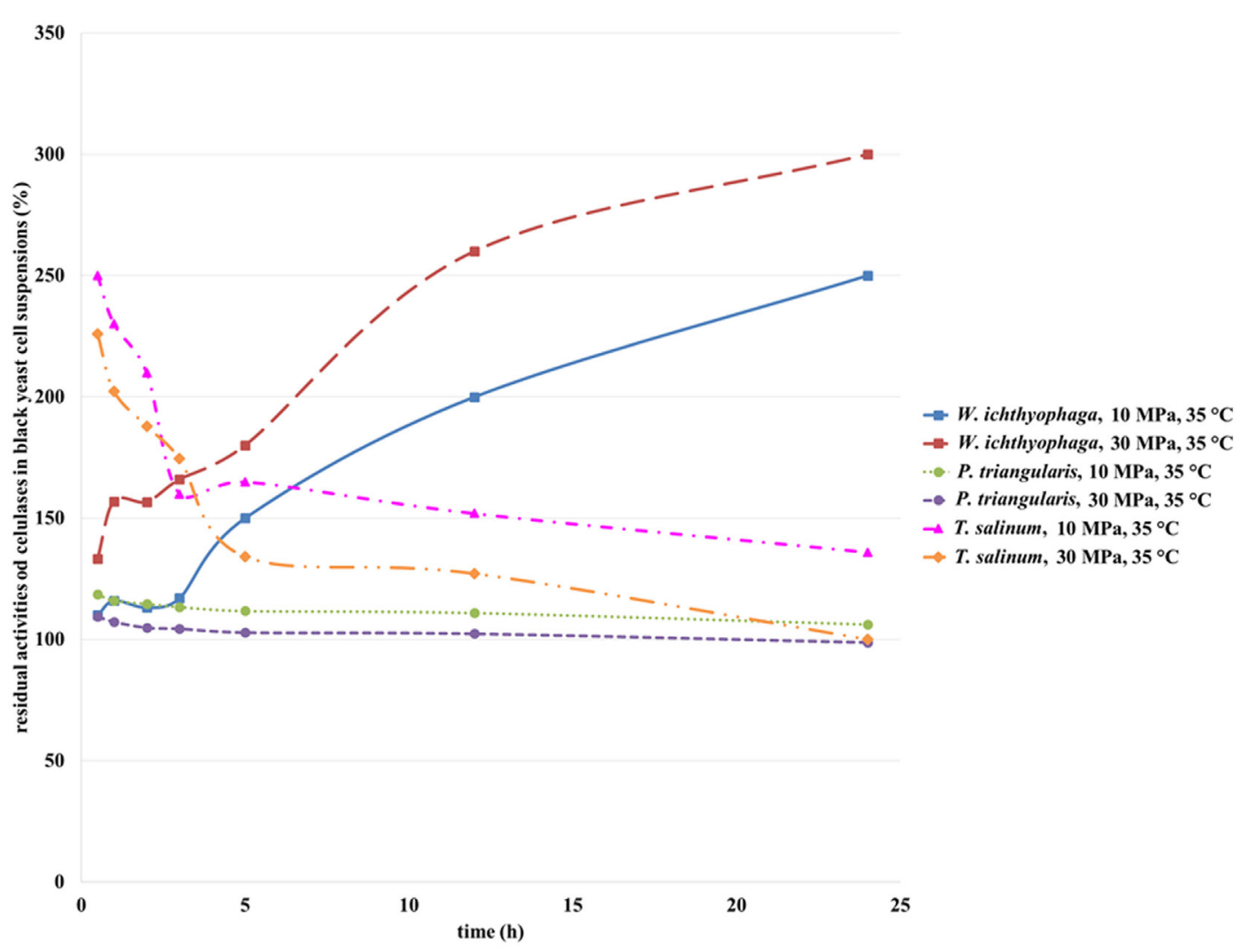

FIGURE 5 | Residual activities of cellulases from W. ichthyophaga, $P$. triangularis, and $T$. salinum after incubation in $\mathrm{SC} \mathrm{CO}_{2}$ at 10 and $30 \mathrm{MPa}$ and at $35^{\circ} \mathrm{C}$ as a function of incubation time.

case of $P$. triangularis and $W$. ichthyophaga, where the cellulase is an intracellular enzyme, and it is more protected from the effects of supercritical medium.

From Figure 5, it could be seen that the activity of cellulase

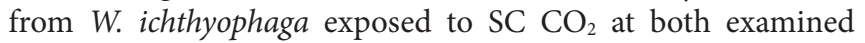
pressures increased as a function of incubation time in $\mathrm{SC} \mathrm{CO}_{2}$. The maximum residual activity of cellulase from $W$. ichthyophaga cell suspension in the $\mathrm{SC} \mathrm{CO}_{2}$ was reached after $24 \mathrm{~h}$ exposure at $30 \mathrm{MPa}, 35^{\circ} \mathrm{C}$ and was amounted to $300 \%$. This can be attributed to a large quantity of extracted cellulase from the cells of $W$. ichthyophaga. Obviously, the cells of W. ichthyophaga contain a large amount of cellulase. No significant difference in cellulase activity from $P$. triangularis at both studied pressures in dependence of incubation time was detected. The reason for this could be in low cellulase concentration in $P$. triangularis cells.

It is evidenced that the pressure influenced the activity of cellulase from T. salinum, where with increase in pressure, the decrease in cellulase activities were determined. Because the cellulase from T. salinum is an extracellular enzyme, the exposure to $\mathrm{SC} \mathrm{CO}_{2}$ could be the reason for its fast deactivation.

\section{Residual Activities of $\alpha$-Amylases}

$\alpha$-Amylase can be isolated from plants, animals, or microorganisms. It is produced by many bacteria. The most frequently used source for the commercial production of the $\alpha$-amylases are
Bacillus amyloliquefaciens and Bacillus licheniformis (de Souza and de Oliveira Magalhães, 2010; Sundarram and Thirupathihalli, 2014).

Enzymes produced from these microorganisms show promising prospects in many industrial applications, such as food, fermentation, textile, and paper industries. Bacillus licheniformis produces thermostable $\alpha$-amylase, which is of most importance, since the hydrolysis of the starch is carried out at high temperatures. Thermostable enzymes were studied in order to improve industrial processes of starch degradation and are useful for the production of valuable products, such as glucose, maltose, and dextrose. Sources of $\alpha$-amylase from fungi are mainly limited to isolates of Aspergillus species (Senyay-Oncel and YesilCeliktas, 2011) and some species of Penicillium (Sundarram and Thirupathihalli, 2014).

$\alpha$-Amylases from T. salinum (Zalar et al., 2005b), W. ichtyhyphaga, and $P$. triangularis are intracellular enzymes (personal communication, Zalar and Gunde-Cimerman, 2010). The activity of $\alpha$-amylase from black yeast cells before incubation in SC $\mathrm{CO}_{2}$ was defined as $100 \%$. After incubation of the cell suspensions in $\mathrm{SC} \mathrm{CO}_{2}$, the $\alpha$-amylase activity was increased due to opening of the T. salinum and W. ichtyhyphaga cells and the elimination of the enzyme in the medium. The activity of $\alpha$-amylase from T. salinum increased during the first $5 \mathrm{~h}$ of incubation in $\mathrm{SC} \mathrm{CO}_{2}$ at both studied pressures (Figure 6), but with longer incubation time, 


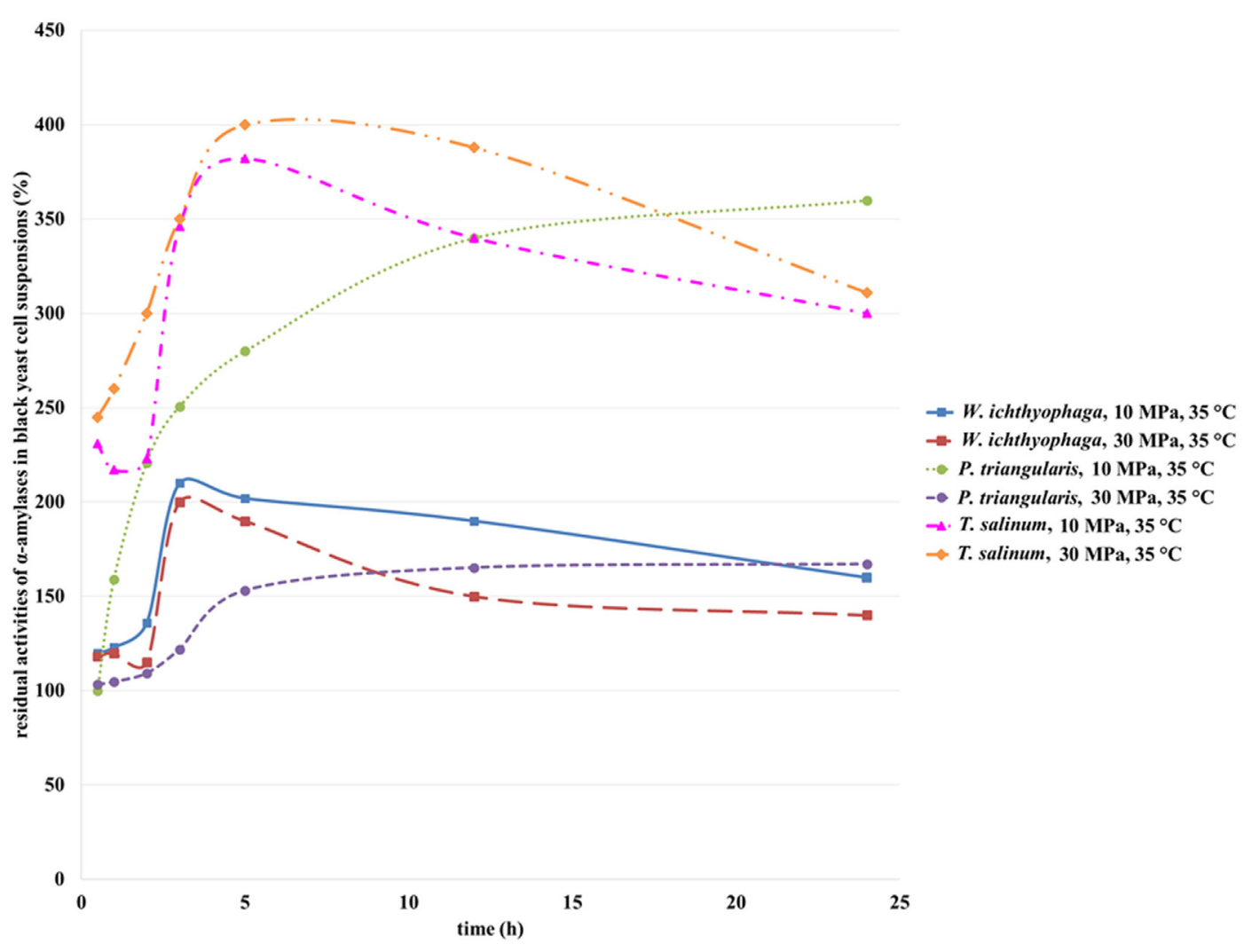

FIGURE 6 | Residual activities of $\alpha$-amylases from W. ichthyophaga, $P$. triangularis, and $T$. salinum after incubation in $\mathrm{SC} \mathrm{CO}_{2}$ at 10 and $30 \mathrm{MPa}$ and at $35^{\circ} \mathrm{C}$ as a function of incubation time.

the $\alpha$-amylases activity decreased. The highest residual activity of $\alpha$-amylase in T. salinum cell suspension was achieved after $5 \mathrm{~h}$ of incubation in $\mathrm{SC} \mathrm{CO}_{2}$ at $30 \mathrm{MPa}, 35^{\circ} \mathrm{C}$ (Figure 6) and was detected to be $400 \%$. At this incubation time, the most of the cells were opened and the enzyme was released in the cell suspension. With higher incubation time, $\alpha$-amylase was deactivated due to the prolonged contact with $\mathrm{SC} \mathrm{CO}_{2}$. When the $W$. ichityophaga cell suspension was exposed to $\mathrm{SC} \mathrm{CO}_{2}$, increase in residual activity of $\alpha$-amylase was detected during first $3 \mathrm{~h}$ of incubation in $\mathrm{SC}_{\mathrm{CO}_{2}}$. With further increase in incubation time, a decrease in residual activity of $\alpha$-amylase at both studied pressures was detected. Higher residual activities were determined at lower studied pressure, which indicates the fact that higher pressure has a negative influence on the activity of intracellular $\alpha$-amylase. The reason for such activity loss could be due to high pressure, which could cause deactivation of enzymes or most probably due to the change in $\mathrm{pH}$ of cell suspension owing to formation of carbonic acid by the contact of water with pressurized $\mathrm{CO}_{2}$.

Residual activity of $\alpha$-amylase from $P$. triangularis increased with the increase of incubation time regardless of the selected pressure. Higher residual activity of $\alpha$-amylase was detected at lower pressure $(10 \mathrm{MPa})$. Since $\alpha$-amylase from $P$. triangularis is an intracellular enzyme, the increase in its activity is connected with the cell opening due to $\mathrm{SC} \mathrm{CO}_{2}$ influence and release of the enzyme into the cell suspension. It is obvious that $\alpha$-amylase from $P$. triangularis is less sensitive to $\mathrm{SC} \mathrm{CO}_{2}$ than $\alpha$-amylase from T. salinum and $W$. ichityophaga since its activity remains the same (30 $\mathrm{MPa})$ or even increases $(10 \mathrm{MPa})$ at higher incubation times.

\section{Residual Activities of $\beta$-Glucosidases}

$\beta$-Glucosidases are present in bacteria, fungi, plants, and animals. Fungi produced $\beta$-glucosidase is an enzyme that breaks down cellulose and works in synergy with endoglucanases and cellobiohydrolases. They split cellobiose into two molecules of glucose, protecting the above mentioned enzymes from the product inhibition effect of cellobiose. Most of the $\beta$-glucosidases from bacteria and fungi are mainly intracellular enzymes. Molds secrete their enzymes extracellularly. Most of these microbial enzymes have an optimum $\mathrm{pH}$ in an acidic range and are active in a broad range of $\mathrm{pH}$. Also important is the resistance of these enzymes to higher temperature, since some biotechnological processes take place at high temperatures. The temperature range in which the $\beta$-glucosidase is active is from 25 to $75^{\circ} \mathrm{C}$ (Kirsch et al., 2010).

Their application in the conversion of high-cellulose-content biomass to fermentable sugars for the production of fuel ethanol is an intensively studied area. Good $\beta$-glucosidase-producer fungi, usable in various biotechnological processes, synthesize these enzymes with high hydrolyzing activity, heat and glucose 


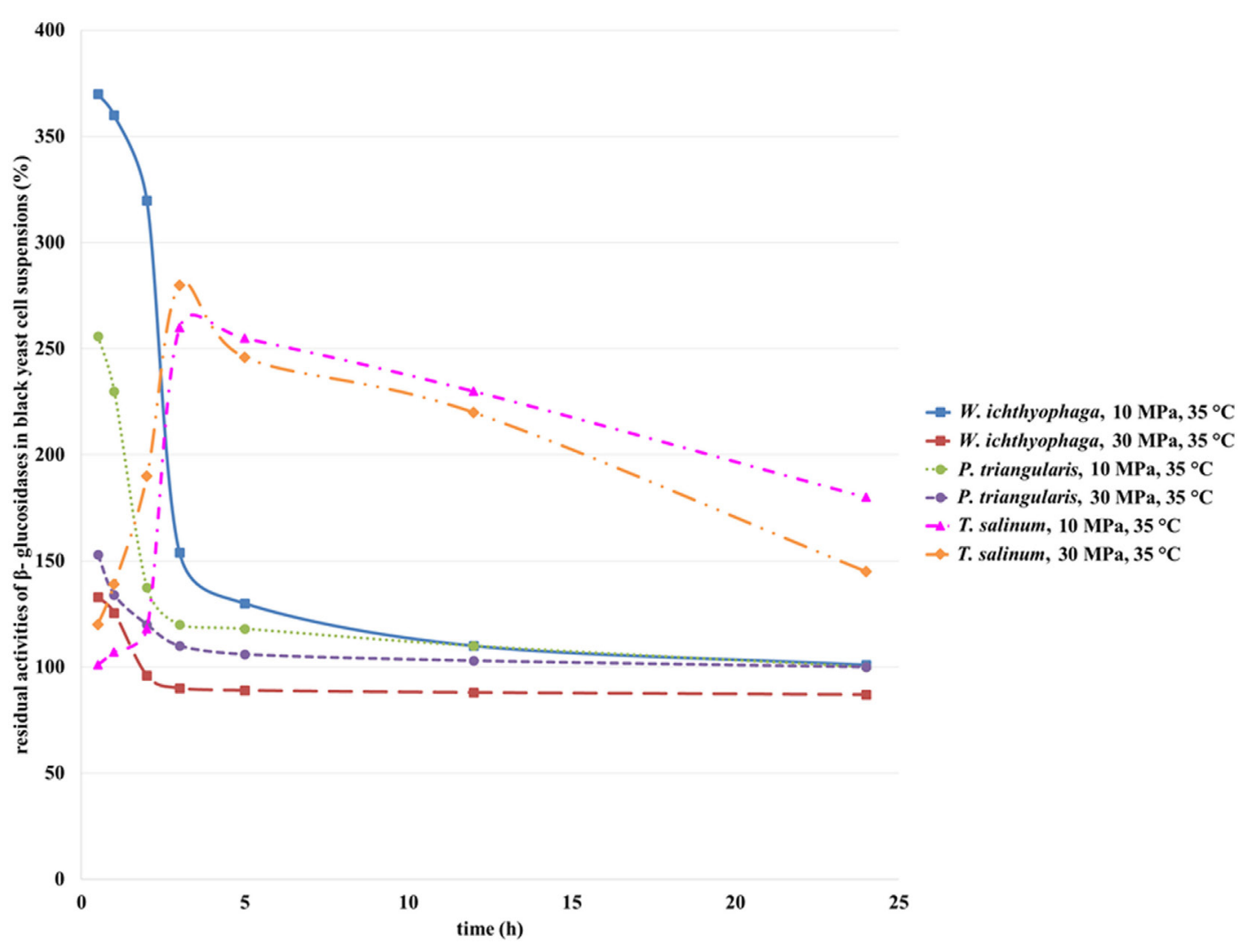

FIGURE 7 | Residual activities of $\beta$-glucosidases from W. ichthyophaga, $P$. triangularis, and $T$. salinum after incubation in SC CO ${ }_{2}$ at 10 and 30 MPa and at $35^{\circ} \mathrm{C}$ as a function of incubation time.

tolerance, acid resistance, and possible transglycosylase activity (Kirsch et al., 2010).

$\beta$-Glucosidases from all three treated black yeasts are extracellular enzymes (Zalar et al., 2005b) (personal communication, Zalar and Gunde-Cimerman, 2010). The activity of $\beta$-glucosidase from black yeast cells before incubation in $\mathrm{SC} \mathrm{CO}_{2}$ was defined as $100 \%$. As can be seen from the Figure 7 , with an increase in incubation time, a decrease in $\beta$-glucosidase residual activities from $W$. ichthyophaga and $P$. triangularis were detected. The highest residual activity was detected for $\beta$-glucosidase from W. ichthyophaga treated in $\mathrm{SC}^{-C_{2}}$ at $10 \mathrm{MPa}, 35^{\circ} \mathrm{C}$ for $30 \mathrm{~min}$. With an increase in incubation time, a significant loss in residual activity was observed. After $24 \mathrm{~h}$ of incubation of $W$. ichthyophaga cell suspension in $\mathrm{SC} \mathrm{CO}_{2}$ at $10 \mathrm{MPa}$ and $35^{\circ} \mathrm{C}, \beta$-glucosidase reached the same activity as in untreated cell suspension. When the W. ichthyophaga cell suspension was incubated in SC $\mathrm{CO}_{2}$ at $30 \mathrm{MPa}$, already after $2 \mathrm{~h}$ only $96 \%$ of residual activity was detected. Higher residual activity of $\beta$-glucosidase from $P$. triangularis was observed at lower studied pressure (10 MPa), and the highest residual activity was reached when the $P$. triangularis cell suspension was incubated in $\mathrm{SC} \mathrm{CO}_{2}$ at $10 \mathrm{MPa}$ and $35^{\circ} \mathrm{C}$ for $30 \mathrm{~min}$.

The residual activity of $\beta$-glucosidase in T. salinum cell suspension increased with increase in incubation time from $30 \mathrm{~min}$ to $3 \mathrm{~h}$. Additional increase in incubation time caused a decrease in its residual activity at both studied pressures. The highest residual activity of $\beta$-glucosidase in T. salinum cell suspension (280\%) was observed at $10 \mathrm{MPa}, 35^{\circ} \mathrm{C}$, and incubation time, $5 \mathrm{~h}$.

Obviously, the increase in incubation time of studied black yeasts in $\mathrm{SC} \mathrm{CO}_{2}$ influences the residual activity of $\beta$-glucosidase. High pressure together with long treatment time in $\mathrm{SC} \mathrm{CO}_{2}$ led to deactivation of $\beta$-glucosidase.

\section{Residual Activities of Proteases}

Proteases occur in all organisms, from prokaryotes to eukaryotes and viruses. These enzymes catalyze multitude of reactions from simple digestion of food proteins to highly regulated cascades. Most commercial proteases are derived from microorganisms belonging to the order Bacillus. An example of a high alkaline protease activity was detected in Penicillium chrysogenum. The enzyme produced by microorganisms occurs in detergents and textile industries. Fungi that occur in natural habitats with variable environmental conditions are important from an industrial point of view, because they produce new metabolites and enzymes with hyperactive catalytic properties (Sethi and Gupta, 2015).

Proteases in cell suspensions of T. salinum (Zalar et al., 2005b) and $W$. ichthyophaga are intracellular enzymes, while the protease from $P$. triangularis cells is an extracellular enzyme (personal communication, Zalar and Gunde-Cimerman, 2010). With an increase in incubation time of $W$. ichthyophaga cell suspension 


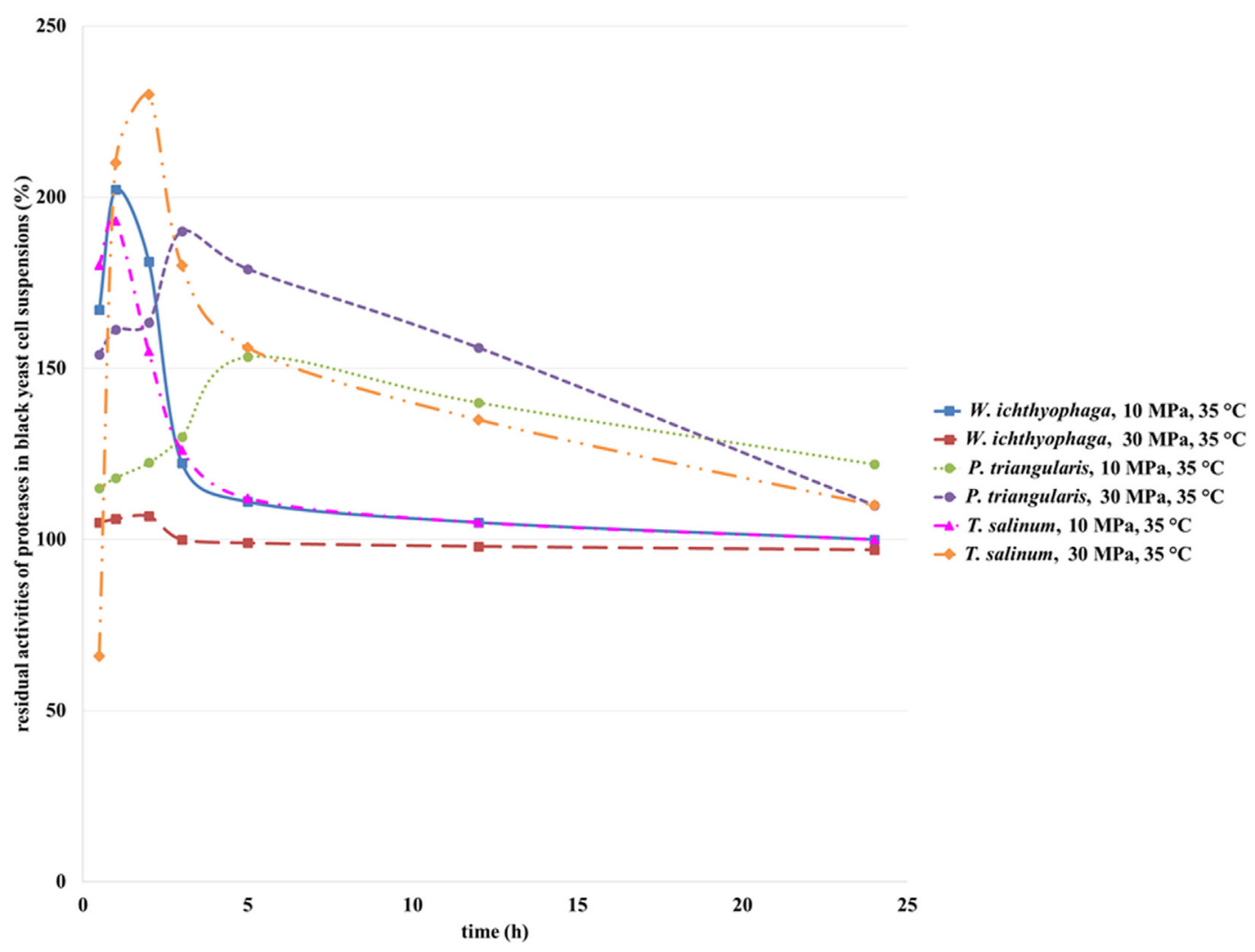

FIGURE 8 | Residual activities of proteases from W. ichthyophaga, $P$. triangularis, and $T$. salinum after incubation in SC $\mathrm{CO}_{2}$ at 10 and $30 \mathrm{MPa}$ and at $35^{\circ} \mathrm{C}$ as a function of incubation time.

in $\mathrm{SC} \mathrm{CO}_{2}$ at $10 \mathrm{MPa}$ and $35^{\circ} \mathrm{C}$ up to half an hour, an increase in residual activity of protease was detected (Figure 8). With additional increase in incubation time, a decrease in residual activity was observed. No significant changes in activity of proteinase from $W$. ichthyophaga cell suspensions at higher pressure (30 MPa) were detected.

The residual activity of protease from $T$. salinum cell suspension increased with higher incubation time in $\mathrm{SC} \mathrm{CO}_{2}$ up to $2 \mathrm{~h}$ at $30 \mathrm{MPa}$ and up to $1 \mathrm{~h}$ at $10 \mathrm{MPa}$ and then by prolongation of incubation time in $\mathrm{SC}_{2}$, a decrease in residual activities of proteases was observed. Obviously, high pressure and longer incubation time influenced this enzyme and reduced its activity.

Due to earlier inactivation of T. salinum cells during incubation in $\mathrm{SC} \mathrm{CO}_{2}$ and the consequent earlier opening of cells, the residual activity of protease from $T$. salinum after $2 \mathrm{~h}$ of incubation in $\mathrm{SC} \mathrm{CO}_{2}$ reached its maximum (230\%). Further, with increase in incubation time, deactivation of enzyme occurred. In contrast to T. salinum, the inactivation of W. ichthyophaga cells occured later, but with the lengthening of incubation time in SC $\mathrm{CO}_{2}$ deactivation of protease appeared, as well.

In Table S2 in Supplementary Material, the maximum residual activities of selected enzymes in black yeasts cell suspensions at different conditions are presented.

As could be seen from the Table S2 in Supplementary Material, for all selected enzymes in black yeasts suspensions, very high maximum residual activities after incubation in $\mathrm{SC} \mathrm{CO}_{2}$ were detected. In the cases of cellulase, $\alpha$-amylase, and protease (intracellular enzymes), high residual activities of enzymes were probably reached due to $\mathrm{SC} \mathrm{CO}_{2}$ influence on cell opening and release of the enzyme into the cell suspension. The highest maximum residual activities were detected at higher pressure and shorter incubation time. Obviously, prolongation of incubation time in $\mathrm{SC} \mathrm{CO}_{2}$ has a negative influence on residual activity of enzymes, because it causes their deactivation. Since cellulase is an intracellular enzyme of $W$. ichthyophaga, the highest maximum residual activity of cellulase in $W$. ichthyophaga cell suspension is attributed to a large quantity of extracted cellulase from the cells of $W$. ichthyophaga. High pressure and long incubation time in $\mathrm{SC} \mathrm{CO}_{2}$ have enabled opening of the cells, and subsequently, the higher amount of cellulase was released from the cells.

\section{CONCLUSION}

Enzymes are favorable catalysts for the development of environmentally benign industrial process. Therefore, the use of microbial enzymes is a key step in the development of industrial bioprocesses. Using whole cells as a source of biocatalysts generate less waste and allow the application of industrial processes in milder conditions. Furthermore, biocatalysis using whole cell eliminates the need for enzyme purification and immobilization. 
The advantage of using $\mathrm{SC} \mathrm{CO}_{2}$ in biocatalysis is in the fact that it can act as a medium for opening the cells and carrying out the biocatalytical reaction at the same time.

Influence of pressure and incubation time of $\mathrm{SC} \mathrm{CO}_{2}$ on the viability of black yeast cells and enzyme activities of cellulase, $\beta$-glucosidase, protease, and $\alpha$-amylase was studied. From the black yeast cells during the $\mathrm{SC} \mathrm{CO}_{2}$ treatment, a significantly high amount of proteins was released. Based on obtained results, it can be concluded that various enzymes in their active form can be released from cells, which were previously incubated in $\mathrm{SC} \mathrm{CO}_{2}$. Thus obtained enzymes from microbial cells could be used for further applications, e.g., for the cascade reactions, where for the synthesis of a particular product a number of different enzymes are required.

\section{AUTHOR CONTRIBUTIONS}

MČ carried out all the experiments and wrote the manuscript. MP participated in manuscript writing, data interpretation and

\section{REFERENCES}

Bradford, M. M. (1976). A rapid and sensitive method for the quantitation of microgram quantities of protein utilizing the principle of protein-dye binding. Anal. Biochem. 72, 248-254. doi:10.1016/0003-2697(76)90527-3

Ceni, G., Fernandes Silva, M., Valério, C. Jr., Cansian, L., Oliveira, R., Dalla Rosa, J. V., et al. (2016). Continuous inactivation of alkaline phosphatase and Escherichia coli in milk using compressed carbon dioxide as inactivating agent. J. CO2 Util. 13, 24-28. doi:10.1016/j.jcou.2015.11.003

Darani, K. K., and Mozafari, M. R. (2009). Supercritical fluids technology in bioprocess industries: a review. J. Biochem. Tech. 2, 144-152.

Debs-Louka, E., Louka, N., Abraham, G., Chabot, V., and Allaf, K. (1999). Effect of compressed carbon dioxide on microbial cell viability. Appl. Environ. Microbiol. $65,626-631$

Erkmen, O. (2003). Mathematical modeling of Saccharomyces cerevisiae inactivation under high-pressure carbon dioxide. Nahrung 47, 176-180. doi:10.1002/ food. 200390041

Garcia-Gonzalez, L., Geeraerd, A. H., Spilimbergo, S., Elst, K., Van Ginneken, L., Debevere, J., et al. (2007). High pressure carbon dioxide inactivation of microorganisms in foods: the past, the present and the future. Int. J. Food Microbiol. 117, 1-28. doi:10.1016/j.ijfoodmicro.2007.02.018

Geciova, J., Bury, D., and Jelen, P. (2002). Methods for disruption of microbial cells for potential use in the dairy industry-a review. Int. Dairy J. 12, 541-553. doi:10.1016/S0958-6946(02)00038-9

Gunde-Cimerman, N., Zalar, P., de Hoog, S., and Plemenitas, A. (2000). Hypersaline waters in salterns - natural ecological niches for halophilic black yeasts. FEMS Microbiol. Ecol. 32, 235-240. doi:10.1016/S0168-6496(00)00032-5

Hong, S., and Pyun, Y. (2001). Membrane damage and enzyme inactivation of Lactobacillus plantarum by high pressure $\mathrm{CO}_{2}$ treatment. Int. J. Food Microbiol. 63, 19-28. doi:10.1016/S0168-1605(00)00393-7

Ji, H., Zhang, L., Liu, S., Qu, X., Zhang, C., and Gao, J. (2012). Optimization of microbial inactivation of shrimp by dense phase carbon dioxide. Int. J. Food Microbiol. 156, 44-49. doi:10.1016/j.ijfoodmicro.2012.02.020

Karthikeyan, V., and Santosh, S. W. (2009). Isolation and partial characterization of bacteriocin produced from Lactobacillus plantarum. Afr. J. Microbiol. Res. 3, 233-239.

Krisch, J., Takó, M., Papp, T., and Vágvölgyi, C. (2010). "Characteristics and potential use of $\beta$-glucosidases from Zygomycetes", in current research, technology and education topics in applied microbiology and microbial biotechnology, ed. A. Méndez-Vilas. Formatex Research Center, Vol. 2. 891-896.

Kogej, T., Gorbushina, A. A., and Gunde-Cimerman, N. (2006). Hypersaline conditions induce changes in cell-wall melanization and colony structure in corrected the manuscript. ŽK made short literature review. ML participated in study conception, data interpretation, and corrected the manuscript. All authors have read and approved the final manuscript.

\section{ACKNOWLEDGMENTS}

The authors would like to thank Slovenian Research Agency (Project "Magnetic nanoparticles as potential carriers of biologically active substances," Contract No. J2-4232) and programme Extraction Processes and Product Design (Contract No. P2-0046). Special thanks go to Prof. Dr. Nina Gunde-Cimerman, University of Ljubljana, Biotechnical Faculty, Slovenia for donation of black yeasts.

\section{SUPPLEMENTARY MATERIAL}

The Supplementary Material for this article can be found online at http://journal.frontiersin.org/article/10.3389/fbioe.2016.00033

a halophilic and a xerophilic black yeast species of the genus Trimmatostroma. Mycol. Res. 110, 713-724. doi:10.1016/j.mycres.2006.01.014

Kuhad, C. R., Gupta, R., and Singh, A. (2011). Microbial cellulases and their industrial applications. Enzyme Res. 2011, 1-11. doi:10.4061/2011/280696

Kutty, N. S. (2009). Marine Yeasts from the Slope Sediments of Arabian Sea and Bay of Bengal. Dissertation/Master's thesis, Cochin University of Science and Technology, Cochin.

Manas, P., and Pagan, P. (2005). Microbial inactivation by new technologies of food preservation. J. Appl. Microbiol. 98, 1387-1399. doi:10.1111/j.1365-2672.2005.02561.x

Mun, S., Hahn, J. S., Lee, Y. W., and Yoon, J. (2011). Inactivation behavior of Pseudomonas aeruginosa by supercritical $\mathrm{N}_{2} \mathrm{O}$ compared to supercritical $\mathrm{CO}_{2}$. Int. J. Food Microbiol. 144, 372-378. doi:10.1016/j.ijfoodmicro.2010.10.022

Ortuño, C., Martínez-Pastor, M. T., Mulet, A., and Benedito, J. (2012). Supercritical carbon dioxide inactivation of Escherichia coli and Saccharomyces cerevisiae in different growth stages. J. Supercrit. Fluids 63, 8-15. doi:10.1016/j. supflu.2011.12.022

Raghukumar, C. (2012). Biology of Marine Fungi. Berlin, Heidelberg: Springer-Verlag.

Rosa, C. A., and Peter, G. (2006). Biodiversity and Ecophysiology of Yeasts. Berlin, Heidelberg: Springer-Verlag.

Senyay-Oncel, D., and Yesil-Celiktas, O. (2011). Activity and stability enhancement of $\alpha$-amylase treated with sub- and supercritical carbon dioxide. J. Biosci. Bioeng. 112, 435-440. doi:10.1016/j.jbiosc.2011.07.012

Sethi, S., and Gupta, S. (2015). Optimization of protease production from fungi isolated from soil. Int. J. Appl. Biol. Pharm. 6, 149-155.

de Souza, P. M., and de Oliveira Magalhães, P. (2010). Application of microbial $\alpha$-amylase in industry - a review. Braz. J. Microbiol. 41, 850-861. doi:10.1590/ S1517-83822010000400004

Spilimbergo, S., Bertucco, A., Lauro, F. M., and Bertoloni, G. (2003). Inactivation of Bacillus subtilis spores by supercritical $\mathrm{CO}_{2}$ treatment. Innov. Food Sci. Emerg. Technol. 4, 161-165. doi:10.1016/S1466-8564(02)00089-9

Sterflinger, K. (2006). Black Yeast and Meristematic Fungi: Ecology, Diversity and Identification, Vol. 20. Germany: Berlin Heidelberg: Springer, 501-514.

Sundarram, A., and Thirupathihalli, P. K. M. (2014). $\alpha$-amylase production and applications: a review. Appl. Environ. Microbiol. 2, 166-175. doi:10.12691/ jaem-2-4-10

Wimmer, Z., and Zarevúcka, M. (2010). A review on the effects of supercritical carbon dioxide on enzyme activity. Int. J. Mol. Sci. 11, 233-253. doi:10.3390/ ijms11010233

Zajc, J., Kogej, T., Ramos, J., Galinski, E. A., and Gunde-Cimerman, N. (2014). The osmoadaptation strategy of the most halophilic fungus Wallemia ichthyophaga, 
growing optimally at salinities above $15 \% \mathrm{NaCl}$. Appl. Environ. Microbiol. 80 , 247-256. doi:10.1128/aem.02702-13

Zalar, P., de Hoog, G. S., and Gunde-Cimerman, N. (1999). Trimmatostroma salinum, a new species from hypersaline water. Stud. Mycol. 43, 57-62.

Zalar, P., de Hoog, G. S., Schroers, H. J., Frank, J. M., and Gunde-Cimerman, N. (2005a). Taxonomy and phylogeny of the xerophilic genus Wallemia (Wallemiomycetes and Wallemiales, cl. et ord. nov.). Antonie Van Leeuwenhoek 87, 311-328. doi:10.1007/s10482-004-6783-x

Zalar, P., Kocuvan, M. A., Plemenitaš, A., and Gunde-Cimerman, N. (2005b). Halophilic black yeasts colonize wood immersed in hypersaline water. Botanica Marina 48, 323-326. doi:10.1515/bot.2005.042
Conflict of Interest Statement: The authors declare that the research was conducted in the absence of any commercial or financial relationships that could be construed as a potential conflict of interest.

Copyright $\odot 2016$ Čolnik, Primožič, Knez and Leitgeb. This is an open-access article distributed under the terms of the Creative Commons Attribution License (CC BY). The use, distribution or reproduction in other forums is permitted, provided the original author(s) or licensor are credited and that the original publication in this journal is cited, in accordance with accepted academic practice. No use, distribution or reproduction is permitted which does not comply with these terms. 